\title{
K:D-Rib: cancer cell proliferation inibitor and DNAzyme folding promoter
}

\author{
Luca Bruni, 1,2,3 Simonetta Croci, \\ ${ }^{1}$ Unit of Biophysics and Medical Physics, Department of Neuroscience, University of Parma; \\ ${ }^{2}$ INBB National Institute of Biostructures and Biosystems, Rome, Italy; ${ }^{3}$ Valsè Pantellini Foundation, \\ Oviedo, Spain
}

\begin{abstract}
We report the effects of $\mathrm{K}: \mathrm{D}-\mathrm{Rib}$, a D-ribose and $\mathrm{KHCO}_{3}$ water solution on HTB-126 human cancer cell line proliferation and the preliminary ultraviolet-visible (UV-VIS) measures of DNAzyme as biosensor of extracellular $\mathrm{K}^{+}$concentration. On the one hand, we demonstrate that the synergic action of $\mathrm{KHCO}_{3}$ and D-ribose from one side has a cytostatic effect on human breast cancer cell line increasing by $30 \%$ the doubling population time of treated cells with respect to the control; and on the other hand we demonstrate how it seems to permit the $\mathrm{K}^{+}$uptake.
\end{abstract}

\section{Introduction}

A significant increase in $\mathrm{K}^{+}$channel expression, $\mathrm{K}^{+}$current and/or $\mathrm{K}^{+}$efflux, can be correlated with tumorigenesis and proliferation. ${ }^{1}$ The effects of K:D-Rib, a water solution of D-ribose and $\mathrm{KHCO}_{3}$, on HTB126 cell (human breast cancer cell line) proliferation is reported. This study also shows preliminary results on DNAzyme used as biosensor to

Correspondence: Luca Bruni, Unit of Biophysics and Medical Physics, Department of Neuroscience, University of Parma, via Volturno 39/E, 43125 Parma, Italy.

Tel. +39.0521.033879 - Fax: +39.0521.903900.

E-mail: luca.bruni@nemo.unipr.it

Key words: HTB-126 cell line, DNAzyme, cancer, K+ ion and D-ribose.

Funding: this investigation was supported by the Valsè Pantellini Foundation, Oviedo, Spain, and Fondazione Cariparma, Parma, Italy.

Acknowledgements: we give hearty thanks to the Biochemistry Section of S.Bi.Bi.T Department, University of Parma and to Prof. I. Ortalli for many helpful discussions and suggestions.

(C) Copyright L. Bruni and S. Croci, 2014

Licensee PAGEPress, Italy

Journal of Biological Research 2014; 87:2135

doi:10.4081/jbr.2014.2135

This article is distributed under the terms of the Creative Commons Attribution Noncommercial License (by-nc 3.0) which permits any noncommercial use, distribution, and reproduction in any medium, provided the original author(s) and source are credited. measure extracellular $\mathrm{K}^{+}$. Cell membranes are permeable to D-ribose but, without $\mathrm{Na}^{+} /$sugar symporter unlike glucose. ${ }^{2}$ Under physiological conditions, the $\mathrm{K}^{+}$intracellular concentration is around $150 \mathrm{mM}$, while the extracellular concentration is about $5 \mathrm{mM} . \mathrm{K}^{+}$is involved in Gquadruplex folding ${ }^{3}$ and in the apoptotic pathway. ${ }^{4}$ G-quadruplex and hemin together form hemin-G-quadruplex nanostructures called DNAzyme $^{5}$ with a catalytic activity horseradish peroxidase-like. We employed the DNAzyme as extracellular $\mathrm{K}^{+}$biosensor to monitor the $\mathrm{K}^{+}$concentration. Following the DNAzyme formation by means of UVVIS spectra acquisition, we measured the $\mathrm{K}^{+}$uptake after K:D-Rib treatment. The DNAzyme folding occurs in spectroscopy buffer containing $\mathrm{K}^{+}$. We compared the amount of DNAzyme formed using cell growth medium containing K:D-Rib, supernatant of cells incubated with K:D-Rib, cell growth medium without treatment and supernatant of untreated cells.

\section{Materials and Methods}

\section{Cells and culture conditions}

According to Croci et al., ${ }^{6}$ except for cell medium, Dulbecco's modified eagle medium (DMEM) without red phenol (Lonza) was used.

\section{Drugs}

Two hundred and fifty mM K:D-Rib: $0.15 \mathrm{~g}$ of D-ribose (Sigma Aldrich, St. Louis, MO, USA) and $0.3 \mathrm{~g}$ of $\mathrm{KHCO}_{3}$ (BHD) mixed into 4 $\mathrm{mL}$ of distilled water.

\section{Dnazyme folding}

Five hundred mM of PS5.M (DNA-TE buffer stock solution frozen) was thawed at room temperature (RT), heated at $95^{\circ} \mathrm{C}$ for $5 \mathrm{~min}$ and let to cool back at RT, $500 \mathrm{mM}$ of PS5.M solution are diluted up to $1.5 \mathrm{mM}$ in spectroscopy buffer (50 mM MES, pH 6.2; $100 \mathrm{mM}$ Tris acetate, DMSO $1 \%[\mathrm{v} / \mathrm{v}]$ and Triton X-100 5\% [w/v]) provided with $0.5 \mathrm{~mL}$ of $\mathrm{K}^{+}$solution for 30 min at RT, to allow proper G-quadruplex folding. After $100 \mathrm{mM}$ of DMSO hemin stock solution was added to G-quadruplex folded solution getting hemin concentration of $0.5 \mathrm{mM}$, for $20 \mathrm{~min}$ at RT.

\section{$\mathrm{K}^{+}$solutions}

Four $\mathrm{K}^{+}$solutions were prepared, one for each sample measured: supernatant of cells treated with $5 \mathrm{mM} \mathrm{K}$ :D-Rib, supernatant of control cells, cell free DMEM with $5 \mathrm{mM}$ K:D-Rib and cell free DMEM. All the solutions were incubated at $37^{\circ} \mathrm{C}$ for $48 \mathrm{~h}$.

\section{Optical measurements}

Jasco 6200 spectrometer (Jasco Inc., Oklahoma City, OK, USA) was used to acquire the UV-VIS spectra at RT. 


\section{Results}

\section{Proliferation assay}

In Figure 1 the best fits of control (C) and treated (T) cell data obtained with the following equation are reported:

$$
\operatorname{In}_{2}(N)=d+\operatorname{In}_{2}\left(N_{0}\right)
$$

where $N$ is proportional to the number of cells at t time, $N_{0}$ is proportional to the seeded cell number and $d$ is the doubling population (DP) time. As reported in Figure 1, the linear regression of T data has a slope that is different to $\mathrm{C}$ data, with a consequent different DP time: $\mathrm{d}_{\mathrm{T}}=59 \pm 2 \mathrm{~h}$ and $\mathrm{d}_{\mathrm{C}}=44 \pm 1 \mathrm{~h}$. The $\mathrm{t}$-test has a value $\mathrm{t}=3.114>\mathrm{tc}=2.571$ $(\mathrm{P}=0.05)$.

\section{DNAzyme like a $\mathrm{K}^{+}$biosensor}

In Figure 2 the spectra UV-VIS of DNAzyme are reported. The DNAzyme UV-VIS absorbance peaks are at 404, 503 and $629 \mathrm{~nm}^{7}$

DNAzyme spectra in presence of cell free DMEM treated with $5 \mathrm{mM}$ $\mathrm{K}: \mathrm{D}-\mathrm{Rib}$ has the highest absorbance value at $404 \mathrm{~nm}$ with respect to all the other sample spectra. The DNAzyme spectrum in presence of treated HTB-126 cell supernatant has a significantly higher absorption at $404 \mathrm{~nm}$ with respect to both spectra in presence of cell free DMEM and control HTB-126 cell supernatant.

\section{Discussion}

The results reported in Figure 1 prove that K:D-Rib, water solution of D-ribose and $\mathrm{KHCO}_{3}$, at the concentration of $5 \mathrm{mM}$ decreases the HTB126 cell line proliferation as shown by the significative duplication time increase. The preliminary results (Figure 1) seem to indicate that the sample, prepared with supernatant of the HTB-126 cell line treated with $5 \mathrm{mM}$ K:D-Rib up to $48 \mathrm{~h}$ has a concentration of DNAzyme lower compared to the one prepared with cell free DMEM incubated with $5 \mathrm{mM}$ K:D-Rib.

\section{Conclusions}

Since DNAZyme folding occurs in presence of $\mathrm{K}^{+}$, these evidences demonstrate that $\mathrm{K}^{+}$enters into the cells and that the DNAzyme can be used as a biosensor for measuring the $\mathrm{K}^{+}$concentration.

\section{References}

1. Wang ZG. Roles of $\mathrm{K}+$ channels in regulating tumour cell proliferation and apoptosis. Pflug Arch Eur J Phys 2004;448:274-86.

2. Gillies RJ, Robey I, Gatenby RA. Causes and consequences of increased glucose metabolism of cancers. J Nucl Med 2008;49:24S$42 \mathrm{~S}$.

3. Parkinson GN, Ghosh R, Neidle S. Structural basis for binding of porphyrin to human telomeres. Biochemistry 46:2390-7.

4. Hughes FM, Bortner CD, Purdy GD, Cidlowski JA. Intracellular K+

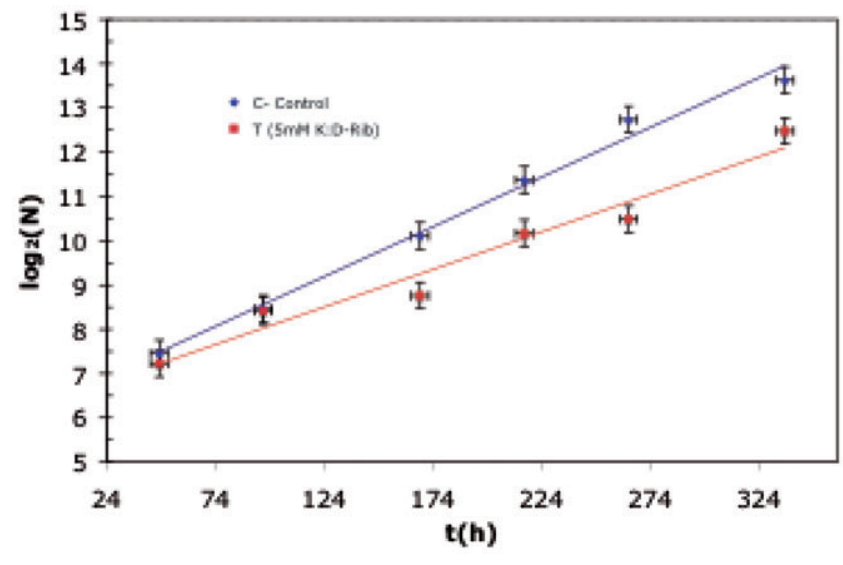

Figure 1. Best fits of cell number against incubation time of control (blue diamond) and treated cells (red square). The linear regressions have a different slope.

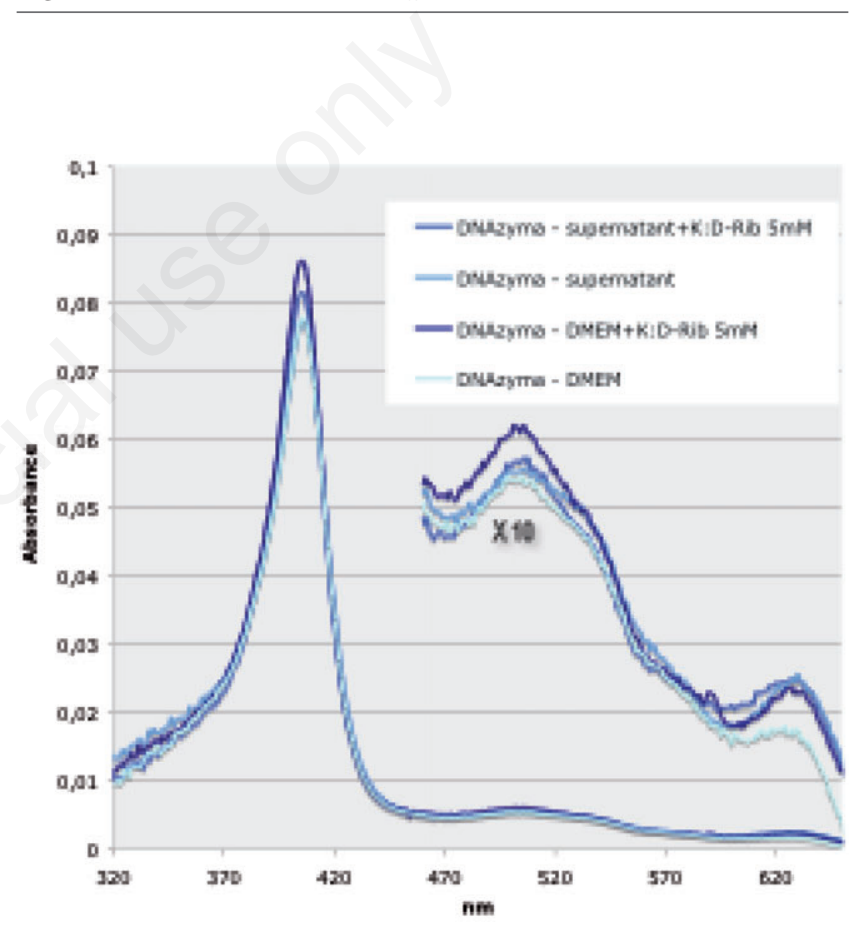

Figure 2. UV-VIS spectra of DNAzyme. On the right part of the figure, under the legend, the ten fold VIS spectra of DNAzyme are reported.

suppresses the activation of apoptosis in lymphocytes. J Biol Chem 1997;272:30567-76.

5. Freeman R, Sharon E, Teller C, et al. DNAzyme-like activity of hemin-telomeric G-quadruplexes for the optical analysis of telomerase and its inhibitors. ChemBioChem 2010;11:2362-7.

6. Croci S, Bruni L, Bussolati S, et al. Potassium bicarbonate and Dribose effects on A72 canine and HTB-126 human cancer cell line proliferation in vitro. Cancer Cell Int 2011;11:30.

7. Travascio P, Li YF, Sen D. DNA-enhanced peroxidase activity of a DNA aptamer-hemin complex. Chem Biol 1998 5:505-17. 